\title{
Negotiating teacher identity: Exploping the use of electronic teaching portfolios with preservice English teachers
}

\author{
Heidi L. Hallman
}

The tension between mastery and inquiry presents a challenge for new teachers. The e-portfolio can be a place to balance that tension and present a cohesive teacher identity.

Kari Morris (pseudonym), a preservice teacher enrolled in the English Education program at State University, sat down one day with me (her student teaching supervisor) and showed me the additions she had made to her electronic teaching portfolio. She told me that these additions were especially important because she had secured her first job interview, scheduled to take place in a week. I asked her why she had waited to make the additions to her e-portfolio until after the grading period for the university course in which she was enrolled. Those additions to her e-portfolio would not count toward her grade in the course.

"Well," Kari sighed, "You know that the professor wants us to be all reflective and represent ourselves as inquirers. But you know what? I don't really think that's what schools want. You know, I want to look confident-not like I'm questioning everything."

Kari's comments about negotiating her identity as a beginning teacher within an elec- tronic teaching portfolio led me to frame an investigation of preservice teachers' use of e-portfolios at State University (pseudonym), a public university in the Midwestern United States. Throughout the course of a semester-long study to investigate the identity-building processes of preservice English teachers, I learned that Kari's comments were not unusual. As she told me, deciding how to represent oneself as a beginning teacher within an e-portfolio is not a simple task; it requires complex negotiations of context, self, and text. Throughout my work with Kari, discussions concerning the negotiations she undertook in the space of her e-portfolio caused me to question not only the content of preservice teachers' e-portfolios, but also required me to reconceptualize how preservice teachers thought about their emerging identities as represented in the space of e-portfolios.

In this article, I consider the negotiating process that preservice teachers undertake when constructing an electronic teaching portfolio. Specifically, I look at comments made by two preservice teachers, Anne Jenkins (pseudonym) and Kari. The conversations I had with Kari and Anne spoke to the feelings these two women had concerning how the e-portfolio authoring process influenced who they were-and possibly could be-as beginning teachers. Building upon work 
that has documented how the identity-building process of beginning teachers is fluid, multiple, and situated (Britzman, 2003; Connelly \& Clandinin, 1999; Knowles, 1992), this study of electronic teaching portfolios aims to illustrate the ways that the use of e-portfolios within teacher education programs is implicated in the process of becoming a teacher. Further, this study seeks to understand the reasons why preservice teachers frequently try to present coherent and competent identities as beginning professionals while also undertaking the notion of identity building as a fluid, ongoing process. Preservice teachers, responding to mandates of the "teacher as professional" and the "teacher as inquirer," find creative ways to represent this dualism within their e-portfolios.

Though commonly thought about as a dissonant dualism, it is perhaps possible to think about how "teacher as professional" and "teacher as inquirer" can coexist as concepts that lead preservice teachers to productive talk about identity. Through highlighting Kari and Anne's comments about the process of authoring their e-portfolios, I argue that teacher educators may conceptualize future uses with electronic teaching portfolios as doing this very thing-eliciting talk about teacher identity. In making the term identity central to my study, I recognize that the creation of one's identity is always connected with the use of Discourses (Gee, 1999, 2001). Discourses act as "identity kits," and come complete with the "appropriate costume and instructions on how to act, talk, and often write, so as to take on a particular role that others will recognize" (Gee, 2001, p. 526). Crafting an identity as a teacher, then, supposes employing particular Discourses in order to be recognized as a teacher. This process, particularly for beginning teachers, often involves "trying on" a variety of ways of being a teacher. In studies of teachers' identities, the term identity is engaged in multiple ways. However, in my work I characterize identity as Hall (2000) did, viewing it as something which is "not already 'there'; rather, it is a production, emergent, in process. It is situational-it shifts from context to context" (p. xi).
This orientation toward identity assists me in calling attention to the ways preservice teachers "try on" identities depending on the context in which they find themselves.

Although use of the electronic teaching portfolio has emerged as a topic in teacher education that speaks to the integration of new technologies and education of preservice teachers (Strudler \& Wetzel, 2005; Yancey, 2001), thus far, e-portfolios have not been investigated as sites through which to explore the perhaps unanticipated complexities of identity negotiation within digital text. Using electronic portfolios within teacher education programs can work to support preservice teachers' growth and ability for selfreflection, providing a context for ongoing discussions about the construction and negotiation of teacher identity.

\section{Situating the use of electronic portfolios in teacher education programs}

The electronic teaching portfolio (e-portfolio) has gained increasing prominence in teacher education programs across the United States for its usefulness as a tool with the potential to represent beginning teachers' practice (Strudler \& Wetzel, 2005). It has been documented that among the $89 \%$ of schools or colleges of education that use some type of portfolio system for assessment of beginning teachers (Salzman, Denner, \& Harris, 2002), many are moving from hard-copy portfolio form to electronic form. Although it is suggested that use of electronic portfolios within schools and colleges of education is increasing, research has been slow to document the effect of the medium on program development or beginning teachers' practices.

Strudler and Wetzel (2005) noted that the implementation of e-portfolio systems in teacher education programs often has multiple goals that include 
1. documenting the journeys of preservice teachers;

2. promoting or marketing preservice teachers for employment; and

3. guiding students toward meeting the requirements of certification programs.

Because many variations of electronic teaching portfolios exist, it is difficult to generalize about the advantages and disadvantages of implementing e-portfolio systems into any particular teacher education program. When examining the features of electronic portfolios, it is possible, however, to see that some systems stress the digital medium as a showcase for preservice teachers' work, therefore demonstrating a goal toward the mastery of teaching practices. Other e-portfolio systems lean toward creating a space where beginning teachers are encouraged to grapple with their thoughts about teaching. Contrary to a mastery-driven e-portfolio, this latter type of e-portfolio may be characterized more as inquiry driven. For example, an e-portfolio focused on mastery would highly value showcasing lesson plans that were executed particularly well in the classroom, whereas a portfolio driven by inquiry may value the discussion of how a particular lesson plan could be improved.

The dichotomy of mastery and inquiry sits at the crux of the difficulties in negotiating one's teacher identity. Referring to Kari's previous comment about her impending interview, the dichotomy of mastery and inquiry asks whether e-portfolios are meant for beginning teachers to demonstrate knowledge with regard to a particular domain of expertise; or, conversely, if e-portfolios are designed to encourage the development of teaching as ongoing inquiry. Literature documenting the use of e-portfolios in teacher education programs (Strudler \& Wetzel, 2005; Yancey, 2001) stresses both of these goals as typical for e-portfolios, but how are both goals enacted by beginning teachers? What challenges do beginning teachers face when authoring an e-portfolio that stresses both mastery and in- quiry, and what consequences does this have for their emerging identity as teachers?

\section{Theoretical underpinnings: Situating the e-portfolio in the context of "New Times"}

To understand the concept and the use of the electronic teaching portfolio, it must be situated within current times. One aspect of living in "New Times," as some have called our current era (Lankshear, 1997), is the presence of ever-changing technological innovation. Technological innovation, which often goes out of date quickly, has reshaped U.S. society - a society that used to be concerned with the production of material goods (Gee, Hull, \& Lankshear, 1996). In New Times, Gee (2004) has argued that work security is not reliant upon jobs and wages, but upon one's portfolio, "the skills, achievements, and previous experiences that a person owns and that he or she can arrange and rearrange to sell him or herself for new opportunities in changed times" (p. 97). A person's marketability, then, is reliant upon one's ability to essentially switch between and among Discourses (Gee, 1999).

To highlight the ability to switch between Discourses, Gee (1999, 2001, 2004) introduced the term shape-shifting portfolio people to refer to workers in New Times. He stated that "shapeshifting portfolio people see themselves in entrepreneurial terms. That is, they see themselves as free agents in charge of their own selves as if those selves were projects or businesses" (Gee, 2004, p. 105). Shape-shifting portfolio people see their set of skills as capable of being rearranged to fit the job market and are fully willing to rework the presentation of themselves to shapeshift into something else. Preservice teachers find themselves in a similar circumstance and are led to present themselves as shape-shifters. As Kari said, university instructors may want one kind of student and those students' future employers may want a different kind of teacher. How can 
the e-portfolio meet the needs of both of these audiences?

Drawing on the notion of shape-shifting portfolio people helps to create the idea of teacher identity as multiple, fluid, and context dependent. Moreover, the context of New Times situates these ideas in a particular time and place, causing teachers and researchers to consider just how our ever-changing technologies may affect beginning teachers.

\section{The context: State University's e-portfolio system}

State University, the site of my semester-long study, embraces the notion that the use of e-portfolios as part of a teacher education program can offer preservice teachers a tool to further support reflective practice. State University believes the goal of reflective practice can be met while simultaneously fulfilling particular standards aligned with teacher education programs. Barrett (2004) noted that many teacher education programs employ the use of portfolios specifically to meet the needs of requirements of their programs. The multiple teacher certification programs at State University link courses and assignments to particular standards and, as a result, the standards-based language structures a significant portion of the electronic portfolio system at the university. Preservice teachers must designate which standards are met by the assignments and documents they choose to feature in their electronic portfolio. Figure 1 shows a page of Kari's e-portfolio that is specifically dedicated to meeting teacher education standards.

Though shaped in part by standards, one of the intentions of the use of the e-portfolio system at State University is that it exists as a system with the ability to change with the needs of each teacher certification program. This vision, embraced by many of the instructors and staff who work with e-portfolios, manifests itself in many of the features of the system itself. Although the template of the e-portfolio is the same for stu- dents in multiple teacher certification programs (see Figure 2), features such as the online threaded discussion board (see Figure 3 ) have evolved at the request of instructors of particular courses. Use of new features like the threaded discussion board has prompted preservice teachers to think that the e-portfolio aims at the following two goals: representing one's teaching practice through the mastery of standards as well as challenging one's practice through ongoing inquiry. Using one textual space, like the e-portfolio, to document both goals (mastery and inquiry) has proven to be difficult, if not impossible, for students like Kari and Anne.

\section{Data generation and analysis}

This article is the first published result of a larger study that investigated the identity-building processes of preservice English teachers. Data were generated as part of a semester-long ethnographic study of six preservice teachers, all of whom were student teachers at the time of the study. As their student teaching supervisor, I was able to observe their teaching four times per student as well as interview all six students in pairs three times throughout the semester. The rationale for conducting interviews in pairs involved an intention to elicit dialogue between two students that would more authentically reveal their feelings and perceptions about the teacher education program. The data presented here draw on dialogue between two students, Kari Morris and Anne Jenkins.

Kari and Anne were enrolled in the Secondary English Education program at State University and could be considered typical of students enrolled in all of the teacher education programs offered at State. Both Kari and Anne grew up and attended school for their entire lives within a two-hour radius of State University. Their white, middle class background often led them to consider themselves similar to others in the program. 


\section{Figure 1}

\section{The Standards page ( $S$ tandards 1-3) of Kari Morris's e-portfolio}

\section{Kari Morris English Teacher}

\section{State University's Teaching Standards}

\section{Evidence of the standard being met is provided for each standard.}

\section{Standard \#1: Incorporates Understanding of Human Learning and Development}

Teachers design learning environments and pedagogical practices for students that are grounded in concepts and interpretative frameworks provided by disciplines that study human development and learning.

My Teaching Philosophy, "Voices at Work" meets Standard \#1 because it describes my classroom environment and pedagogy in the English curriculum based on who I am and what I believe about education.

\section{Standard \#2: Understands the Social Context of Schooling}

Teachers understand how local, state, national, and global social and political contexts differentially affect schooling and its outcomes for students.

My Teaching Story, "The First Battle in the 43rd War" meets Standard \#2 because it depicts an experience I had in a middle school classroom that shaped the way I view learning and educational goals for students in ESL programs and students with learning disabilities.

\section{Standard \#3: Demonstrates Sophisticated Curricular Knowledge}

Teachers understand the central concepts, assumptions, tools of inquiry, ways of reasoning, uncertainties, and controversies of the disciplines that they teach to students.

The Becoming Your Character lesson plan meets Standard \#3 because it anticipates problems that students may have during the unit in hopes to prevent them. It also anticipates students' needs for learning in that it breaks down writing into manageable tasks and asks students to participate in the stages of writing with support from conferencing with me.

Interviews conducted with the participants in the study yielded data coded as relevant to preservice teachers' views of the electronic portfolio and the ways issues of identity were taken up in this space. A constant comparative method (Strauss \& Corbin, 1990) was used throughout the analysis of data, and findings were compared with coded data in field notes and interview transcripts. The analysis of data presented in this article relied on discourse analytic techniques (Gee,
1999) to closely consider the content of the interviews with Kari Morris and Anne Jenkins.

As their field supervisor, I often had conversations with Kari and Anne regarding issues that are raised in this article. To limit the scope of the article, however, I chose to highlight Kari and Anne's perceptions of the authoring process of their e-portfolios and the negotiations they made in constructing a teacher identity within a digital space. 


\section{Figure 2}

\section{The front page of Kari Morris's e-portfolio}

\author{
Kari Morris \\ English Teacher \\ 1234 Ivy Street \\ Lakeville, XX \\ 00000
}

Teaching Philosophy

Teaching \& Learning

Technology

Collaboration

Autobiography

Standards
Read my philosophy on teaching titled, "Voices at Work."

My virtual classroom-View a variety of lessons and activities that I have implemented in the middle school and high school English teacher.

View a Power Point presentation of a Holocaust Unit I designed for 9th grade.

The International Poetry Guild, a web-based poetry community, allowed my students to collaborate with other high school poets and University mentors.

View who I am-personally and as a teacher. Includes my resume, autobiographical information, and an in-depth explanation of my student teaching experience.

Tracks the University standards and how I have met them in the past two years.

\section{Interpretations and findings}

The following sections highlight the findings from interviews with Kari Morris and Anne Jenkins. These findings are specifically focused on the ways the e-portfolio worked as a tool to help preservice teachers represent mastery and inquiry in their practice and negotiate an identity as a beginning teacher. The findings also support a complex understanding of what kinds of negotiations preservice teachers undertake in the space of electronic teaching portfolios.

\section{Becoming shape-shifting portfolio people}

Anne Jenkins commented that she wished she had time to create two separate portfolios-one for future employers and one for university instructors. Claiming these two audiences "want different things," Anne eventually told me that she would have to choose the audience for her e-portfolio. She said,

\footnotetext{
I hesitate to say that the university and future employers want the same things. I feel like so much this semester is for our instructors at the university and not necessarily for my future employers. I don't know. They're the same in the sense that they are both educationally higher, but they have different purposes. They like, use different language. And so, I guess my e-portfolio has to show that. (Interview transcript, May 6, 2003)
}

The idea of the university and the educational job market using "different languages" ran throughout several exchanges between Anne, Kari, and me. In the above statement, Anne establishes a dichotomy between the university's expectations and the expectations of the public school. Anne's perceptions that the university and the public schools are distinctly different pervaded her comments and remained evident when she and Kari 


\section{Figure 3}

\section{The threaded discussion feature of State University's e-portfolio system}

\section{Kari Morris \\ English Teacher}

\section{Teaching and Learning}

Link to Student Work

\section{Introduction}

\section{Full Lesson}

\section{Childhood Narrative}

Narrative writing became a major focus for "The Examined Self" class. "The Examined Self" was my class that focused on autobiographical writing — reading and writing autobiographies with elements of interpersonal communication skills.

The Childhood Narrative Lesson asks students to begin constructing a personal story about their childhood. Students focused on an event or memory that gives readers insight into their life and who they were. The childhood narrative is the first narrative assignment; those that follow include: coming of age, teenage years, and a future narrative. With each narrative literary elements are introduced for students to use in their writing such as characterization, setting, dialogue, metaphor/simile, verb usage, interior monologue, blocking, sensory imagery, plot structure, etc. The Childhood Narrative Lesson began the learning process about what a personal narrative is and how to use some of the techniques in writing. Students read published narratives and an autobiographical book of their choice to serve as models for their understanding of the autobiographical genre and writing within that genre.

\section{Comments: Start a new discussion}

\section{Needed? (Morris, Kari)}

I think this evidence cluster meets the same standards as my

"Howl" evidence cluster and so my question is—did I justify my standards well and are there any I missed? I don't feel like this is my strongest evidence cluster as far as meeting the standards go. Also, should I show student work? Would any images, handouts, student work, or my syllabus for the class help the evidence cluster further?

\section{Comments List $\quad$ Add your comments}

-re: Needed? (Hallman, Heidi)

-re: Needed? (A Classmate) 
talked about the relationship between theory and practice.

The dichotomy between the goals of the university and those of the public school is discussed in work documenting the perceptions of preservice teachers (Britzman 2003; Rose, 1999), and in Anne and Kari's case that dichotomy appears to serve a purpose: It gives them a way to establish their identity in both the space of the university and that of the public school. In the following exchange, Anne and Kari show how they intend to shape-shift when speaking to other educators.

Kari: I'm glad I know those terms...like metacognition, just so I know what it is. But I don't think it's going to enter my vocabulary unless I'm talking at a university level.

Anne: Exactly. I'll only use it when talking to other educators and even then it will probably only be other university level educators or something like that. Or maybe in interviewing to make myself sound all scholarly and interesting.

Kari: I don't think I could do that. I'd sound awkward.

Anne: I think they are really just buzzwords a lot of times. I mean people talk about this stuff all the time without using the words but you need the buzzwords to sound all knowledgeable in your field. I don't think I'll even use them on the e-portfolio. I'm not sure yet. (Interview transcript, May 6, 2003)

In this segment of talk, Kari places the use of certain terms (terms associated with the School of Education) in a particular space, the space of the university. Even though she acknowledges that these terms may exist in the spaces of both the public school and the university, she references the fact that the two Discourses are not static and bounded, but rather fluid (Gee, 1999). She also understands that language is used in different ways, depending on its context of use.

Anne responds to Kari's comments with affirmations and suggests another context in which the vocabulary she associates with the university may be used-the interview. In positioning a particular use of language as appropriate for an interview, she says that using such language would make her sound "all scholarly and interesting." She does not say that the use of this language would prove her scholarship, but rather that it would act as a signifier of scholarship. Anne also hopes to use her ability to shape-shift as a user of certain types of language as an advantage, therefore evoking a particular image of herself as a teacher. Kari responds to Anne's suggestion of using language in this way, claiming that she may "sound awkward" if she tried to do this. Kari then lets Anne know that the use of language in a certain way may not be a true reflection of self, but rather a signifier of an image she possibly could evoke.

Anne's teaching philosophy worked to bridge the two environments in which she took part-her student teaching site and State University's English Education program. Figure 4 shows Anne's teaching philosophy as it appeared on her e-portfolio. The way Anne frames ongoing inquiry is evident in the content of the second paragraph of her teaching philosophy. The third paragraph works to bring the interactions between teacher and students into consideration when crafting a philosophy of teaching.

In considering the dialogue between Anne and Kari, it is apparent that they understand how different spaces may cause one to interpret the same content differently. Anne and Kari recognize the complexity involved in crafting a single textsuch as the e-portfolio-for multiple audiences, while also being aware of what this may mean for their process of becoming teachers. This negotiation or process of shape-shifting is not new. Teachers have always negotiated how identities change in different spaces. However, by suggesting that preservice teachers must create two separate portfolios, one for future employers and one for professors and instructors at the university, Anne indicates that there is something different about crafting her teacher identity within the space of the e-portfolio. Instead of being able to 


\section{Figure 4}

\section{Anne Jenkins's teaching philosophy}

\section{Anne Jenkins English Teacher}

\section{Teaching Philosophy}

Return to Philosophy intro page

Return to Philosophy justification

I remember the day that I got my acceptance letter to the School of Education at State University was one of the most gratifying days of my life. I was so excited that I started shaking and screaming-I could not help thinking "I actually made it into the program. I am going to be a teacher." Of course, my first instinct was to start telephoning people and telling them the news. Everyone seemed genuinely excited for me, except one friend. She asked me: “Anne, are you sure you want to go through with this? You're smart enough to be a doctor, why don't you keep going with that?” This one statement completely tempered my excitement. I was immediately filled with self-doubt—was I making the wrong decision? Is teaching really for me? Will I be fulfilled? Can I handle the fact that most people seem to still believe teaching is a career one settles for, not one a person would actually choose? Despite my doubts, I enrolled in the program, and from the moment I walked into a classroom, I have be certain that I chose the only career that will prove fulfilling and challenging for the rest of my life.

I believe that teachers need to have a passion for what they are doing. Teachers must feel that they can make a difference in students' lives and they need to love working with youth. I have a passion for teaching and each day I student teach I feel that passion growing. With that passion comes a strong desire to constantly reflect on my teaching and continue to learn new teaching methods. I feel that it is very important for teachers to constantly be learning and trying new approaches to teaching. One never knows what might be missed if you do not try new things. I feel that this process of learning and trying new things keeps me fresh and excited about teaching. I have observed too many educators who have decided they know the best way to teach and therefore fall into a rut. They teach the same way day in and day out, which is boring for the students and the teacher.

Throughout my time in the School of Education, I have realized that I believe in two fundamental aspects of education: 1.) My first priority is meeting the need of my students and creating a student-centered classroom 2.) 1 cannot achieve my first goal if I do not help my students create a community of respect. Studentcentered classrooms allow students to take control of and vest interest in their own education. I prefer to give students choices in the classroom. At the beginning of each course I find out what the students want to learn in the course, what aspects of the course worry them, and how they prefer to learn-ie. group work, discussion, reading, writing etc. After thoroughly examining the students' responses, I alter the course where I can to meet the needs and expectations of the students and specifically point out to the students the changes that I made. This initial activity allows the students to see that their opinions and goals do matter to me and they will always be taken into account. To establish community in my classroom, I also start each course with a discussion about my only behavior rule in the class: have respect for yourself, your peers and the teacher. As a class we decide what this rule means and how we will work as a group to stick to the rule. Again, this activity allows the students to see that their opinions are important and help the students feel they are part of a community. From this foundation, I work with my students to create an environment that is academically rigorous, while at the same time, meeting and respecting the various needs of individuals. 
negotiate how language is dependent on context, preservice teachers appear to face a new dilemma when thinking about how to represent themselves and their practice in textual space intended for multiple purposes and audiences.

\section{Simultaneous representation of oneself as both competent teacher and inquisitive student}

Preservice teachers negotiate the ways spoken and written text portray their identities as teachers. Their audiences - the university and the public school interviewers - are the readers of the e-portfolios. However, beginning teachers also state that shifting their language depending on context is not as possible in a written text as it is in spoken discourse. Consequently, they will likely have a more difficult time constructing their identity as beginning teachers within the e-portfolio. Kari and Anne consistently asked who the audience for the e-portfolio was. How does one portray oneself when writing for multiple and sometimes conflicting audiences?

The e-portfolio can be thought about as an instrument designed to transmit information about teaching practices and teacher identity over virtual space. No longer is it necessary that a physical document of representation, such as a hard copy or paper portfolio, be sent to a future employer when an electronic document can be accessed. Conceptualized at State University as a tool that can move between audiences, the e-portfolio is seen as a conduit that takes information from one forum to another. Framed by teacher education standards mandated by the university and that reference university coursework, the e-portfolio also endorses the showcasing of lesson plans preservice teachers use in practicums and student teaching classrooms. This display of these various documents situates the e-portfolio as a kind of virtually paved road between the sites of the university and the schools. It assumes that the work produced by preservice teachers in both sites can merge fluidly.
Anne and Kari found it difficult to see how the content of the e-portfolio could move smoothly from the School of Education to a hiring committee. Though envisioned to serve multiple audiences, Anne and Kari positioned their e-portfolios in various ways in their conversations about the medium, deliberating which positioning would serve them best. Much like choosing spoken language dependent on one's context, these preservice teachers were aware that written text is filled with the politics of knowing how one's words will be perceived in different arenas. In the following conversation, Kari and Anne discussed how to represent oneself as a teacher within the e-portfolio.

Anne: My main concern is getting a job. The purpose of the portfolio is to get a job.

Heidi: If someone said that you have the job you want would you be willing to take more risks in the portfolio?

Kari: I'd be like, cool, I can do freaky things on this portfolio. I mean, not freaky, but I could, just, like, experiment. I could put any, you know what I mean, I would, I would not have to worry so much about how I'd come off in the marketplace.

Anne: I'm not overly concerned about how I come off. If people look at it and don't like it then we're not a good match.

Kari: But don't you feel that you could take more of a risk?

Anne: I'm unsure.... I guess I don't have a desire to take a risk. I'm not really limiting myself, I'm just not sure how I would take a risk. I'm putting up what I want to put up.

Kari: If I had my dream job I might put up one of my first lessons-before I was even in the program and then put up a lesson I have now designed, but I do still want to show my strengths. There's such a tension. (Interview transcript, May 13, 2003)

An examination of this segment of talk finds that Kari feels the tension between crafting an identity for herself and then presenting this identity within the confines of her e-portfolio. Anne and Kari are clearly concerned about how 
they portray themselves to future employers, although Kari seems more concerned about how she would represent herself if there weren't "risks" (coming off poorly to interviewers) than Anne does. Anne acknowledges not taking risks as limiting, but she claims not to feel limited.

Kari is concerned about "how she comes off in the marketplace," introducing the idea of how a written text creates and situates one in an identity. She connects the self that people view her as to the self she depicts on the e-portfolio. Therefore, Kari is concerned with her "voice" in the "sense of the way [she] wants to sound, rather than in the sense of the stance [she] is taking" (Ivanič, 1998, p. 25). In the interview, Kari claims that if she didn't have to construct herself as aligned with particular ideologies, she "could do freaky things." Her construction of an identity as represented in the e-portfolio is clearly limiting her. She claims that it may be important to her to depict her first lessons, before she was in the teacher education program, but she also wants to show her strengths.

The threaded discussion site, a new feature of the e-portfolio at State University, was also a source of tension for Kari and Anne. This feature emerged in the English Education methods course as a way to promote teaching as inquiry. The intent was for the online threaded discussion space to be a place where preservice teachers could question their practices and deliberate about how their practices are informed by their knowledge about teaching.

In the threaded discussion highlighted in Figure 3, Kari wonders about the standards that might be met by her poetry unit. She asks for feedback from her instructor and fellow peers, which they give her. When I asked Kari to reflect on whether the comments she received were helpful, she replied as follows:

Yeah, they were. But I'm actually kind of worried that they're up there. You know, if someone like a future employer would look at it they'd see all these questions about what standards I'm meeting. Like I don't know what I'm doing. And so, I'm kind of concerned about this. Also, besides the questioning, I'm just not sure what it makes me look like. Like, what kind of a teacher is this person? Not really a confident new teacher. (Interview transcript, May 13, 2003)

Kari's comments about the online threaded discussion feature point again to the dichotomy between mastery and inquiry. Kari, when commenting about her use of the discussion feature, looks upon questioning as antithetical to the way a knowledgeable new teacher should be. Kari was reluctant to keep using the online discussion feature, because she knew those discussions about her practice might be seen by her potential employers. She made the following comments about this:

So I know that anyone can see what I write on the discussion board. And I know that I have to do this [post questions] for class, but I sort of don't want to because I don't want to look like I don't know what I'm doing. (Interview transcript, May 13, 2003)

Encouraged by her university instructor to be an inquirer, Kari was asked to post two questions related to each unit on her e-portfolio. As we can see through her comments, this isn't a positive in Kari's mind, for it may jeopardize how she is perceived as a new teacher.

\section{Future use of electronic teaching portfolios: Implications for preservice teachers and teachep educators}

As evidenced by Kari's and Anne's talk, presenting an identity as a beginning teacher within the space of the e-portfolio means making important choices about how to write for multiple audiences. The e-portfolio as a space points out the tension in representing oneself as a beginning teacher and offers evidence of the fact that begin- 
ning teachers must choose what is important within their own representation; they must decide if and how they are to be shape-shifters.

Preservice teachers' feelings of tension when representing themselves as teachers within the e-portfolio may lead many to perceive their identity as fractured or dissonant. In many spaces, the idea of a dissonant identity would be problematic and undesirable. However, when considering the possibilities the e-portfolio affords in thinking about how to negotiate identity within a text, it may be possible to think about dissonance as innovative and creative.

Dissonance in one's teacher identity may be a fruitful subject to be taken up by teacher educators. Teacher educators, as this article illustrates, must be the next step in assisting beginning teachers to use the e-portfolio as a tool to negotiate their teacher identity. A starting point for teacher educators may be to engage their students in conversations about e-portfolios as tools rather than simply as sites in which to showcase good work, to encourage thinking about teaching practice and teacher identity. In an effort to engage in teaching for transformation and social change, teacher educators must recognize the difficulty many preservice teachers have in striving for a balance between being a knowledgeable teacher and an inquisitive student. Perhaps this recognition means that preservice teachers and teacher educators alike must abandon their hope for a one-dimensional identity as a teacher, and instead realize that the path to becoming a teacher must confront and embrace the tensions between mastery and inquiry. Moreover, teacher educators can help beginning teachers recognize that the dissonance they feel in the effort of constructing their identity as beginning teachers should be viewed as constructive.

\section{REFERENCES}

Barrett, H. (2004). Differentiating electronic portfolios and online assessment management systems. In C. Crawford, N. Davis, J. Price, \& D. Willis (Eds.), Technology and teacher education annual (pp. 210-213). Norfolk, VA:
Association for the Advancement of Computing in Education.

Britzman, D.P. (2003). Practice makes practice (Rev. ed.). Albany: State University of New York Press.

Connelly, F.M., \& Clandinin, D.J. (Eds.). (1999). Shaping a professional identity: Stories of educational practice. New York: Teachers College Press.

Gee, J.P. (1999). An introduction to discourse analysis: Theory and method. New York: Routledge.

Gee, J.P. (2001). Literacy, discourse, and linguistics: Introduction. In E. Cushman, E.R. Kintgen, B. Kroll, \& M. Rose (Eds.), Literacy: A critical sourcebook (pp. 525-544). Boston: Bedford/St. Martin's.

Gee, J.P. (2004). Situated language and learning: A critique of traditional schooling. New York: Routledge.

Gee, J.P., Hull, G., \& Lankshear, C. (1996). The new work order: Behind the language of the new capitalism. Boulder, CO: Westview.

Hall, S. (2000). Foreword. In D.A. Yon, Elusive culture: Schooling, race, and identity in global times (pp. ix-xii). Albany: State University of New York Press.

Ivanič, R. (1998). Writing and identity: The discoursal construction of identity in academic writing. Philadelphia: John Benjamins.

Knowles, J.G. (1992). Models for understanding pre-service and beginning teachers' biographies: Illustrations from case studies. In I.F. Goodson (Ed.), Studying teachers' lives (pp. 99-152). London: Routledge.

Lankshear, C. (1997). Changing literacies. Buckingham, England: Open University Press.

Rose, C. (1999). Shaping Sara's practice. In F.M. Connelly \& D.J. Clandinin (Eds.), Shaping a professional identity: Stories of educational practice (pp. 42-63). New York: Teachers College Press.

Salzman, S.A., Denner, P.R., \& Harris, L.B. (2002, February). Teaching education outcomes measures: Special study survey. Paper presented at the annual meeting of the American Association of Colleges of Teacher Education, New York, NY.

Strauss, A.L., \& Corbin, J.M. (1990). Basics of qualitative research: Grounded theory procedures and techniques. Newbury Park, CA: Sage.

Strudler, N., \& Wetzel, K. (2005). The diffusion of electronic portfolios in teacher education: Issues of initiation and implementation. Journal of Research on Technology in Education, 37, 411-433.

Yancey, K.B. (2001). Introduction: Digitized student portfolios. In B.L. Cambridge, S. Kahn, D.P. Tompkins, \& K.B. Yancey (Eds.), Electronic portfolios in student, faculty, and institutional learning (pp. 15-30). Washington, DC:

American Association of Higher Education. 